\title{
Stephanie Zammit
}

\section{SUMMER RAIN}

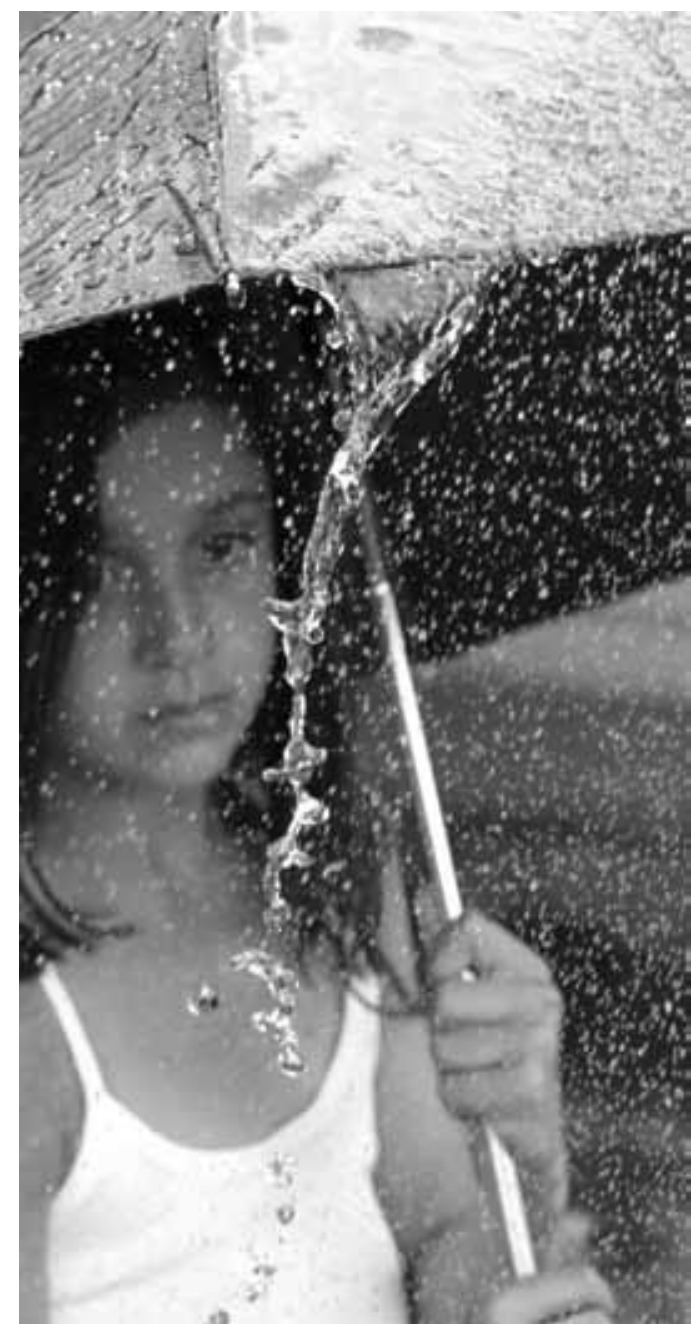

28 Offset no. Io 